\title{
Perancangan Aplikasi Komik Hadist Berbasis Multimedia
}

\author{
Helmi Fauzi Siregar ${ }^{1}$, Yustria Handika Siregar ${ }^{2}$, Melani $^{3}$ \\ ${ }^{1,2,3}$ Fakultas Teknik Jurusan Teknik Informatika Universitas Asahan \\ J1. Jend Ahmad Yani Kisaran Sumatera Utara \\ ${ }^{1}$ fauzi.helmi.hf@gmail.com, ${ }^{2}$ yustriahandikasiregar@gmail.com, ${ }^{3}$ melaniamellg@gmail.com
}

\begin{abstract}
Abstrak - Komik adalah media komunikasi visual yang berisi suatu informasi, ide, pesan yang dituangkan ke dalam gambar semenarik mungkin. Perpaduan antara komik dan hadist cocok digunakan sebagai alternatif media dakwah karena terdapat pesan-pesan moral dan akhlak yang terkandung pada hadist. Aplikasi komik hadist dibuat agar memudahkan pembaca dalam memahami isi cerita komik dan meminimalisir kesalah artian yang sering terjadi. Metode yang digunakan dalam membuat aplikasi adalah dengan menggunakan Php. Aplikasi komik hadist memiliki fitur penyajian komik yang dikolaborasikan dengan animasi, hal ini dimaksudkan agar pengguna menyimak alur cerita komik secara benar dan berurutan sehingga meminimalisir kegagalan dalam memahami inti cerita. Aplikasi komik hadist disertai gambar dan variasi warna yang atraktif membuat aplikasi menarik untuk digunakan terutama bagi kalangan remaja dan anak-anak.
\end{abstract}

Kata Kunci - Aplikasi, Komik Hadits, Informasi, Multimedia

\section{PENDAHULUAN}

Hadist merupakan sumber pokok ajaran Islam dan merupakan rujukan umat Islam dalam memahami syariat dan mengajarakan bagaimana berakhlak sebagai seorang muslim. Komik merupakan salah satu media komunikasi visual yang telah berkembang pesat pada saat sekarang ini baik yang diterbitkan secara konvisional dalam bentuk cetak maupun online. Membaca dapat memperluas wawasan dan juga ilmu yang dimiliki, seperti halnya membaca komik.

Pada masa sekarang ini kurangnya media yang memperlihatkan bagaimana berperilaku baik atau berakhlak yang baik dalam bergaul di tengah-tengah masyarakat berdasarkan hadist sangatlah minim. Terutama untuk kalangan remaja dan anak-anak, sehingga dengan membaca komik hadist ini pembaca akan mendapatkan hiburan sekaligus ilmu, karena pada komik tersebut diselipkan pesan-pesan moral dan akhlak yang baik pada hadist tersebut. Secara tidak sengaja, pembaca akan tertarik untuk mempelajari hadist lebih dalam lagi. data untuk melakukan kenaikan jabatan fungsional dosen selama ini hanya ada pada biro rektor. Sehingga Fakultas Teknik Universitas Asahan dalam melakukan monitoring atau menyamakan data tidak memiliki perekapan/ perekaman seluruh data-data penting dosen dalam melakukan kenaikan jabatan.

Berdasarkan uraian tersebut, maka aplikasi komik hadits yang akan dibangun bertujuan untuk mengubah cara penyampaian dari aplikasi sebelumnya yang menyajikan komik secara manual menjadi komik semi-animasi dalam mendalami ilmu tentang agama. Selain itu juga, akan ditambah beberapa fitur tambahan guna membuat aplikasi komik hadits menjadi semakin menarik untuk dibaca, maka penulis membuat penelitian dengan judul "Perancangan Aplikasi Komik Hadits Berbasis Multimedia"

\section{LANDASAN TEORI}

\section{A. Pengertian Perancangan}

Menurut Nataniel Dengen dan Heliza Rahmania Hatta (2009), perancangan didefinisikan sebagai proses aplikasi berbagai teknik dan prinsip bagi tujuan pendefinisian suatu perangkat, suatu proses atau sistem dalam detail yang memadai untuk memungkinkan realisasi fisiknya. Untuk mengendalikan proses desain, A. Davis mengusulkan serangkaian prinsip-prinsip dasar dalam perancangan sebagai berikut:

1. Desain tidak boleh menderita karena tunnel vision (visi terowongan).

2. Desain tidak boleh berulang.

3. Desain harus terstruktur untuk mengakomodasi perubahan.

4. Desain harus terstruktur untuk berdegradasi dengan baik, bahkan pada saat data dan event-event (kejadian-kejadian) menyimpang atau menghadapi kondisi operasi.

5. Desain bukan pengkodean dan pengkodean bukanlah desain.

6. Desain harus dinilai kualitasnya pada saat desain dibuat, bahkan setelah jadi.

7. Desain harus dikaji untuk meminimalkan kesalahan-kesalahan konseptual (semantik).

\section{B. Pengertian Aplikasi}

Menurut Jogiyanto HM (dalam suhartini (2017), aplikasi merupakan penerapan, menyimpan sesuatu hal, data, permasalahan, pekerjaan ke dalam suatu sarana atau media yang dapat digunakan untuk diterapkan menjadi sebuah bentuk yang baru.

Pengertian aplikasi secara umum adalah alat terapan yang difungsikan secara khusus dan terpadu sesuai kemampuan yang dimilikinya aplikasi merupakan suatu perangkat komputer yang siap pakai bagi user. 


\section{Pengertian Komik}

Menurut Dewi Tresnawati, Eri Satria dan Yudistira Adinugraha (2016), komik adalah suatu bentuk media komunikasi visual yang mempunyai kekuatan untuk menyampaikan informasi secara popular dan mudah dimengerti. Hal ini dimungkinkan karena komik memadukan kekuatan gambar dan tulisan, yang dirangkai dalam suatu alur cerita gambar membuat informasi lebih mudah diserap. Komik merupakan karya seni berupa panel-panel berisi gambar tidak bergerak yang disusun sedemikian rupa menjadi alur cerita, di dalam komik terdapat dialog antar tokoh yang diterapkan melalui balon-balon kata.

\section{Pengertian Hadist}

Menurut Dewi Tresnawati, Eri Satria dan Yudistira Adinugraha (2016), hadits adalah perkataan (sabda), perbuatan, ketetapan dan persetujuan dari Nabi Muhammad SAW, yang dijadikan ketetapan ataupun hukum dalam agama Islam. Hadits dijadikan sumber hukum dalam agama Islam selain Al-Qur'an, ijma dan qiyas dimana dalam hal ini kedudukan hadits merupakan sumber kedua setelah al-qur'an. Ada banyak ulama periwayat hadits, namun yang sering menjadi referensi hadits-haditsnya yakni Imam Bukhari, Imam Muslim, Imam Abu Daud, Imam Tirmidzi, Imam Ahmad, Imam Nasa'i, dan Imam Ibnu Majah. Hadist adalah perkataan dan perbuatan dari Nabi Muhammad SAW. Hadits sebagai sumber hukum dalam agama Islam memiliki kedudukan kedua pada tingkatan sumber hukum di bawah Al-Qur'an.

Termasuk dalam kategori hadits adalah atsar, yaitu sesuatu yang disandarkan kepada para sahabat Nabi Muhammad SAW. Dan juga taqrir, yaitu keadaan Nabi Muhammad SAW yang mendiamkan, tidak mengadakan sanggahan atau menyetujui apa yang telah dilakukan atau diperkatakan oleh para sahabat di hadapan beliau.

\section{E. Pengertia UML(Unified Modeling Language)}

Menurut Ade Hendini (2016), Unified

Modeling Language (UML) adalah bahasa spesifikasi standar yang dipergunakan untuk mendokumentasikan, menspesifikasikan dan membangun perangkat lunak. UML merupakan metodologi dalam mengembangkan sistem berorientasi objek dan juga merupakan alat untuk mendukung pengembangan sistem.

\section{Use Case Diagram}

Use case diagram merupakan pemodelan untuk kelakuan (behavior) sistem informasi yang akan dibuat. Use case digunakan untuk mengetahui fungsi apa saja yang ada di dalam sistem informasi dan siapa saja yang berhak menggunakan fungsi-fungsi tersebut..

\section{Diagram Aktivitas (Activity Diagram)}

Activity Diagram menggambarkan workflow (aliran kerja) atau aktivitas dari sebuah sistem atau proses bisnis. Simbol-simbol yang digunakan dalam activity Diagram yaitu:

3. Diagram Urutan (Sequence Diagram)
Sequence Diagram menggambarkan kelakuan objek pada use case dengan mendepenelitiankan waktu hidup objek dan pesan yang dikirimkan dan diterima antar objek.

4. Diagram Kelas (Class Diagram) merupakan hubungan antar kelas dan penjelasan detail tiaptiap kelas di dalam model desain dari suatu sistem, juga memperlihatkan aturan-aturan dan tanggung jawab entitas yang menentukan perilaku sistem.

5. Package Diagram

Package diagram (diagram paket) adalah sekelompok elemen-elemen model. Sebuah paket dapat berisi elemen-elemen model yang berlainan. Termasuk untuk paket-paket untuk menciptakan/menggambarkan sifat hiraki. Sebuah paket diberi nama yang menggambarkan isinya. Oleh karena itu package dapat digunakan untuk beberapa keperluan dan kebutuhan.

6. Collaboration Diagram Diagram ini bersifat dinamis.Diagram kolaborasi adalah diagram interaksi yang menekankan organisasi struktural dari objek-objek yang menerima serta mengirim pesan (message).

7. Diagram Komponen (Component Diagram)

Component diagram menggambarkan struktur fisik dari kode, pemetaan pandangan logis dari kelas proyek untuk kode aktual di mana logika ini dilaksanakan.

\section{Deployment Diagram}

Deployment diagram memberikan gambaran dari arsitektur fisik perangkat lunak, perangkat keras, dan artefak dari sistem. Deployment diagram dapat dianggap sebagai ujung spektrum dari kasus penggunaan, menggambarkan bentuk fisik dari sistem yang bertentangan dengan gambar konseptual dari pengguna dan perangkat berinteraksi dengan system.

\section{F. Pengertian Multimedia}

Menurut Dewi Tresnawati, Eri Satria dan Yudistira Adinugraha (2016), multimedia merupakan kombinasi teks, seni, suara, gambar, animasi, video, yang disampaikan melalui komputer atau dimanipulasi secara digital dan dapat disampaikan atau dikontrol secara intraktif.

\section{G. PHP (Hypertext Preproceeor)}

Menurut Ajeng Puspitasari, Tengku A. Riza, ST.,MT dan Rohmat Tulloh (2015), PHP (Hypertext Preprocessor) adalah bahasa pemrograman Open Source yang digunakan untuk membuat sebuah aplikasi web. PHP Hypertext Preprocessor merupakan pemrograman server side, yaitu bahasa yang berjalan di sisi server. Kode program PHP akan dieksekusi oleh server dan hasil eksekusi tersebut akan di tampilakn kepada client. Keunggulan PHP adalah sangat sederhana dan mudah dimengerti sehingga cocok untuk pemula maupun tingkat lanjut. Selain itu, karena PHP merupakan Open Source maka PHP dapat 
digunakan di banyak sistem operasi (Windows, Linux, Mac, Solaris, dan lain-lain). Tujuan utama bahasa ini adalah untuk memungkinkan perancang web untuk menulis halaman web dinamik dengan cepat. Struktur pada PHP : yang merupakan struktur pada PHP adalah struktur kendali atau statement yang menjadi bagian penting dalam suatu bahasa pemrograman, karena bagian ini mengatur jalurnya eksekusi suatu program. Struktur penulisan php, dapat dituliskan berdiri sendiri atau disisipkan pada script HTML.

\section{H. Pengertian Notepad ++}

Menurut Angga Reza Palevil dan Krisnawati (2013:4), Notepad++ adalah sebuah aplikasi text editor yang bersifat gratis. Notepad menitik beratkan kegunaan aplikasi untuk editing text dalam waktu yang cepat dan praktis. Notepad ++ mendukung banyak format bahasa pemrograman seperti PHP, HTML, Java Script dan CSS. Aplikasi ini dapat diunduh secara bebas di alamat "notepad-plus-plus.org".

\section{Pengertian Database}

Menurut Andi (dalam Liza Yulianti1 dan Harry Aspriono, 2011), basis data atau Database adalah sekumpulan informasi yang disimpan dalam komputer secara sistematik dan merupakan sumber informasi yang dapat diperiksa menggunakan suatu program komputer dan berfungsi untuk menyimpan informasi atau data.

\section{J. Pengertian MySQL}

Menurut Raharjo (Liza Yulianti1 dan Harry Aspriono, 2011), MySQL merupakan sistem database yang banyak digunakan untuk pengembangan aplikasi web. Karena pengolahan datanya sederhana, memiliki tingkat keamanan yang bagus, dan mudah diperoleh.

\section{K. Pengertian Appserv}

Menurut One Yunita Fujiyati dan Sukadi (2015), appserv adalah alat Open Source untuk windows dengan Apache, MySql, PHP dan penambahan lainya, dimana aplikasi ini diatur secara otomatis yang memungkinkan untuk menjalankan server web sama sekali. Sebagai bonus menggabungkan phpMyAdmin untuk mengelola MySQL. Segera setelah instalasi tersedia sepenuhnya fungsional server web Apache, yang berjalan pada komputer lokal, Anda dapat menjalankan jumlah yang tidak terbatas situs menjadi sangat efektif untuk mengembangkan dan debugging skrip PHP tanpa meng-upload file ke server remote. Program ini didistribusikan secara bebas di bawah lisensi GNU General Public License dan bebas, mudah untuk menggunakan web server mampu melayani halaman dinamis. Dengan konfigurasi ini, Anda dapat menyebarkan dengan cepat tim web server matang dan cepat, dengan akses dari jaringan lokal, tanpa konfigurasi tambahan. Dapat digunakan sebagai web server publik di Internet.

\section{METODE PENELITIAN}

\section{A. Rancangan Penelitian}

Untuk menyusun penelitian ini yang dilakukan penerapan metode penelitianadalam memperoleh data-data yang dibutuhkan sehingga penyusunan penelitian ini dapat diselasaikan dengan baik.

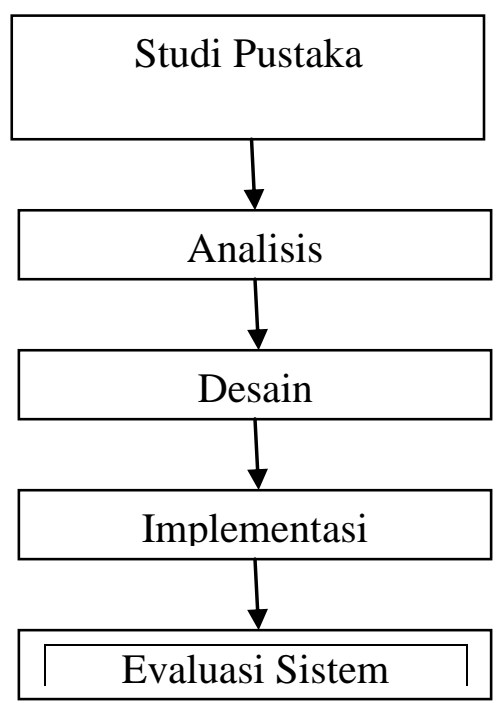

Gambar 3.1 Rancangan Penelitian

\section{B. Teknik Pengimpulan Data}

Pada bab ini akan dijelaskan tentang sumber adan teknik pengumpulan data yang diperoleh peneliti dalam penyusunan penelitian.

\section{Data Primer}

Data primer yang diperoleh secara langsung dari data-data dosen tetap pada Fakultas Teknik Universitas Asahan.

2. Data Sekunder

Data sekunder diperlukan untuk mendukung hasil penelitian. Data tersebut berasal dari jurnal, internet dan berbagai sumber lain yang berhubungan dengan masalah penelitian sehingga memudahkan dalam penyelesaian masalah.

\section{Metode Analisa Data}

Metode analisa data adalah menganalisis data yang berhasil dikumpul untuk mencapai suatu kesimpulan. Analisa data digunakan untuk suatu sistem informasi secara nyata dan bertujuan untuk melakukan identifikasi terhadap masalah yang muncul dan dapat memberikan solusi yang jelas untuk perbaikan ataupun pengembangan dari suatu sistem.

\section{Metode Penelitian}

Dalam pembuatan aplikasi ini, metode yang penulis gdiunakan berupa metode observasi, yang nantinya digunakan untuk memperoleh data-data yang dibutuhan dalam pembuatan aplikasi. Metodeobservasi ini berupa pengumpulan data dari sumer-sumber yang berkitan dengan aplikasi komik hadist. 


\section{ANALISA DAN PEMBAHASAN}

\section{A. Analisa Masalah}

Dalam proses analisa masalah ini ditemukan kendala-kendala yang terjadi dalam proses pengajuan jabatan fungsional dosen. Selama ini difakultas teknik masih menggunakan cara manual atau langsung kebagian pihak kepegawai universitas. Hal ini berdampak kurang efektif sehingga harus dibuat sistem yang dapat diintegrasikan kedalam bagian yang sudah ada.

\section{B. Analisa Input}

Dalam proses analisa input ini dapat diberikan yaitu proses input data pengajuan kepangkatan oleh dosen yang bekerja di universitas asahan.

\section{Analisa Proses}

Dalam analisa proses ini merupakan hasil proses yang diolah oleh admin untuk mendata atau menseleksi dokumen dalam proses pengajuan kenaikan pangkat agar dapat diverfikasi oleh admin sehingga dapat memperoleh hasil.

\section{E. Perancangan Sistem}

1. Use Case Diagram

Perancangan model dengan use case diagram menggambarkan perilaku sistem yang dibuat. Dalam sistem ini yang penulis buat, terdapat 2 aktor yaitu admin, dan user.

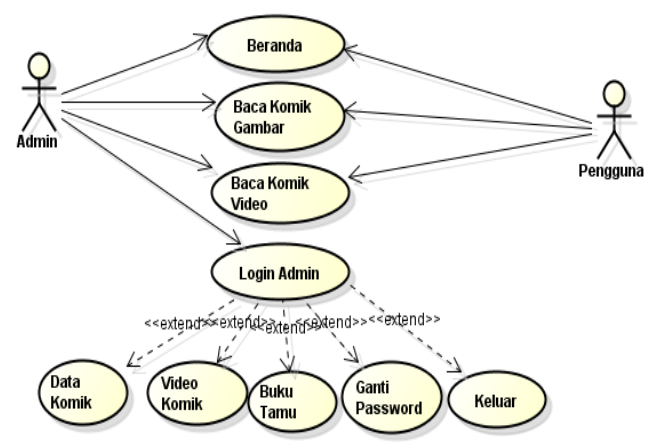

Gambar 4.1 Use Case

\section{Activity Diagram}

Perancangan Activity Diagram mengambarkan bagaimana alur aktivitas yang terjadi antara admin atau user didalam sebuah sistem. Agar lebih jelas berikut di bawah ini gambaran Activity Diagram admin.
1) Activity Diagram Menu Utama

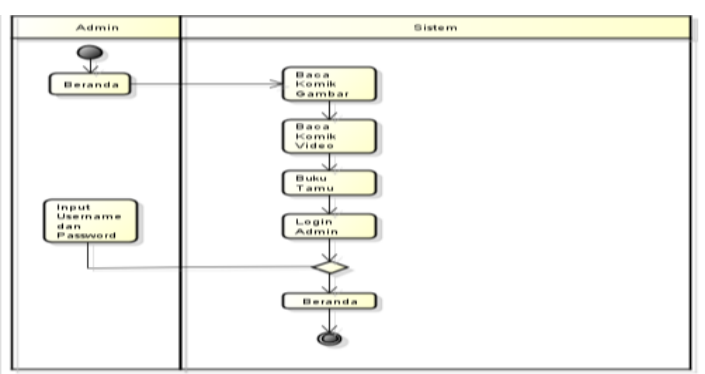

Gambar 4.2 Activity Diagram Menu Utama

2) Activity Diagram Menu Login

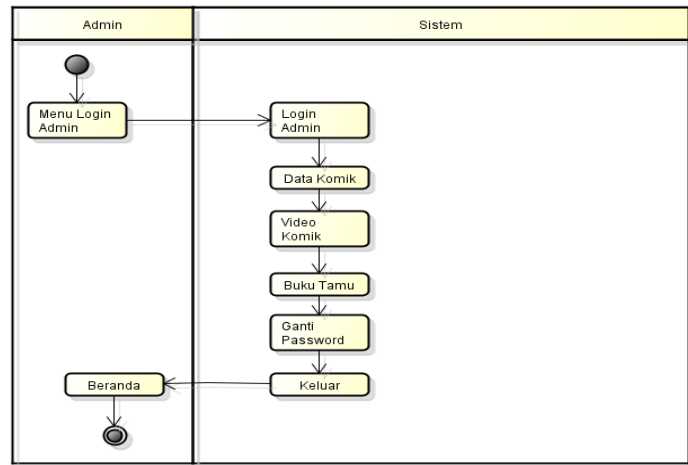

Gambar 4.3 Activity Diagram Menu Login

3) Activity Diagram Pengguna

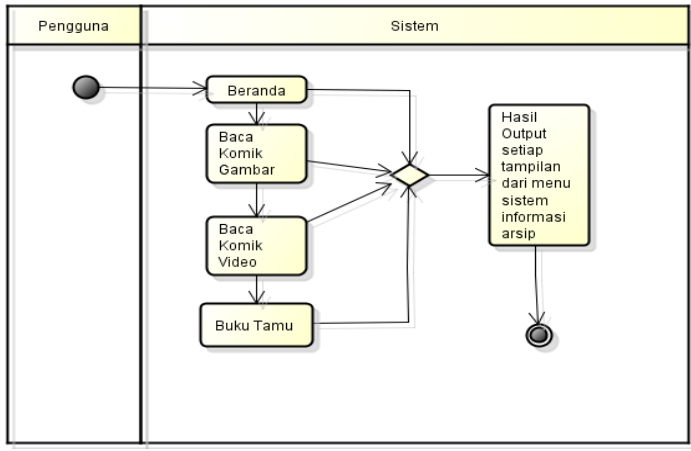

Gambar 4.4 Activity Diagram Pengguna

3. Class Diagram

Dari perancangan diagram akan dapat diketahui bagaimana hubungan antara tabel didalam database dan proses input apa saja yang ada didalamnya. Untuk gambar dapat dilihat dibawah ini. 


\begin{tabular}{|c|c|c|c|}
\hline admin & Berita & Gallery_Video & Tamu \\
\hline \multirow{4}{*}{$\begin{array}{l}\text { - id: Int } \\
\text { - nama:'var } \\
\text { - email'.var } \\
\text { - user'.var } \\
\text { - password 'var }\end{array}$} & \multirow{4}{*}{ 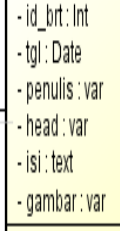 } & \multirow{4}{*}{ 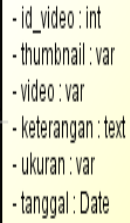 } & \multirow{3}{*}{$\begin{array}{l}\text { - id_tamu: Int } \\
\text { - nama: Var } \\
\text { - alamt:var } \\
\text { - np. Var }\end{array}$} \\
\hline & & & \\
\hline & & & \\
\hline & & & \multirow{2}{*}{$\begin{array}{l}\text { + editto: void } \\
\text { + hapuso: void }\end{array}$} \\
\hline + edilakuno' void & + heritaa: void & + +videoo': void & \\
\hline
\end{tabular}

Gambar 4.5 Class Diagram

\section{Sequence Diagram}

Dari perancangan diagram akan dapat diketahui bagaimana hubungan user dalam sistem dan proses apa saja yang ada didalamnya. Untuk gambar dapat dilihat dibawah ini.

1) Sequence Diagram Menu Utama

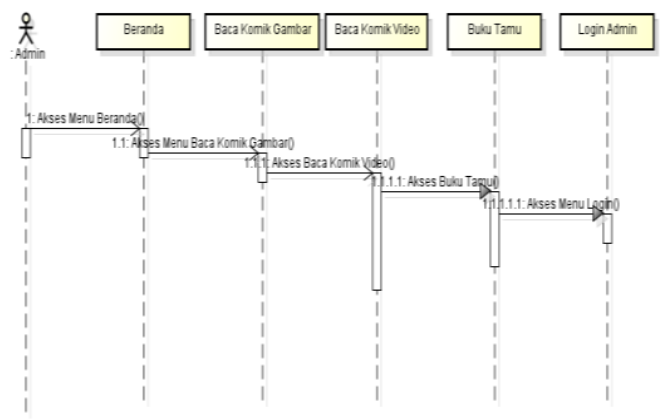

Gambar 4.6 Sequence Diagram Menu Utama

2) Sequence Diagram Menu Login

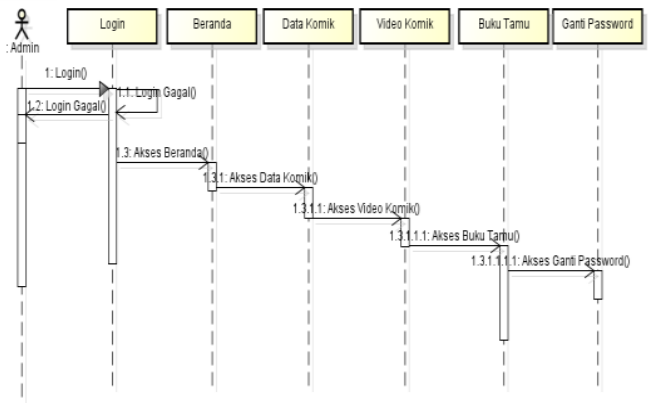

Gambar 4.7 Sequence Diagram Menu Login

3) Sequence Diagram Menu pengguna

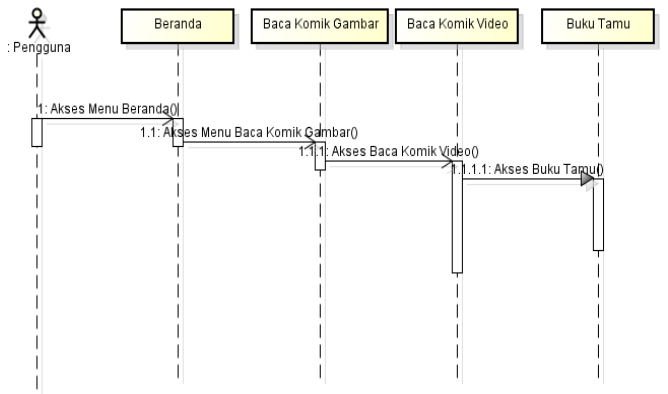

Gambar 4.8 Sequence Diagram Menu Pengguna
5. Collaboration Diagram

Statemachine diagram yaitu salah satu jenis diagram pada UML yang menggambarkan transisi maupun perubahan keadaan suatu objek pada sistem. Untuk gambar dapat dilihat dibawah ini.

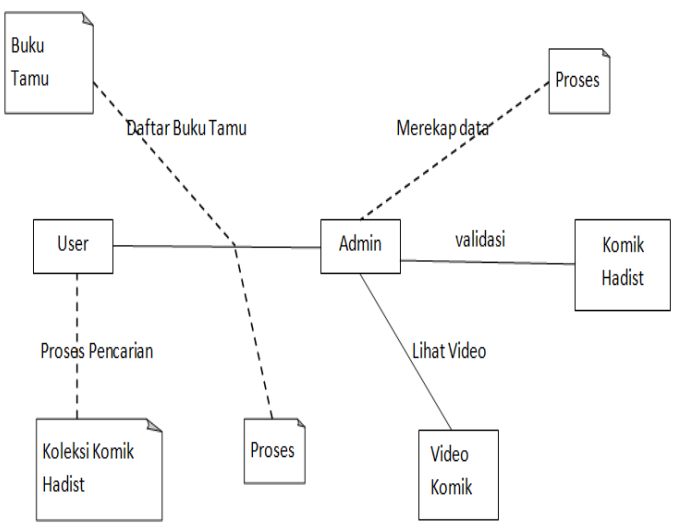

Gambar 4.9 Collaboration Diagram

6. Component Diagram

Component diagram yaitu salah satu jenis diagram pada UML yang menggambarkan software pada suatu sistem. Component diagram merupakan penerapan software dari satu ataupun lebih class, dan biasanya berupa file data atau .exe, source kode, table, dokumen.

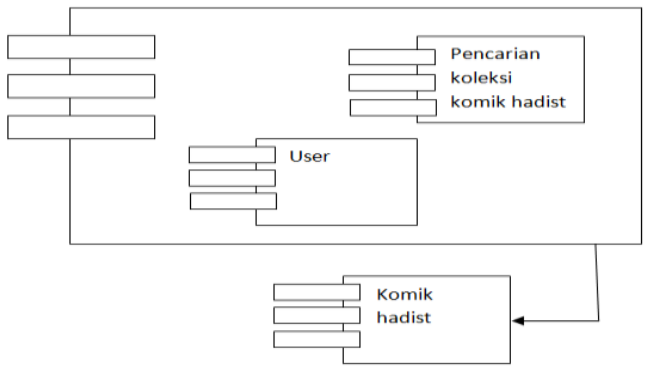

Gambar 4.10 Component Diagram

7. Deployment Diagram

Deployment diagram yaitu salah satu diagram pada UML yang menunjukan tata letak suatu sistem secara fisik, dapat juga dikatakan untuk menampilkan bagian-bagian software yang terdapat pada hardware dan digunakan untuk menerapkan suatu sistem dan hubungan antara komponen hardware. Jadi Deployment diagram yaitu untuk menunjukan letak software pada hardware yang digunakan sistem. 


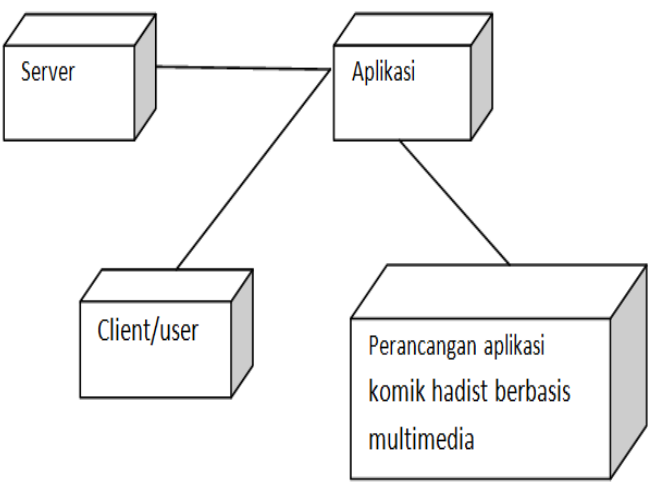

Gambar 4.11 Deployment Diagram

\section{Package Diagram}

Dari perancangan diagram akan dapat diketahui bagaimana menggambarkan prosesor pada diagram. untuk lebih jelas perhatikan gambar berikut.

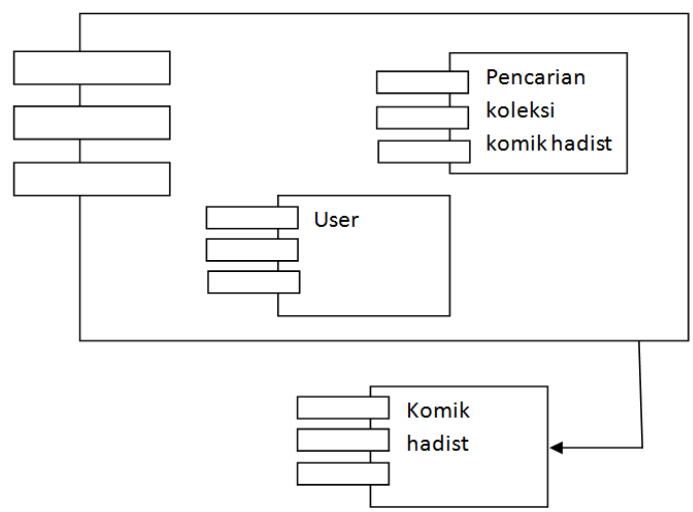

Gambar 4.12 PackageDiagram

\section{E. Perancangan Struktur Menu}

Pada perancangan ini terdapat menu yang dapat mengintegrasikan seluruhdata dalam suatu sistem yang disertai dengan intruksi-intruksi yang ada pada pilihan menu tersebut berikut rancangan menu aplikasi sebagai berikut :

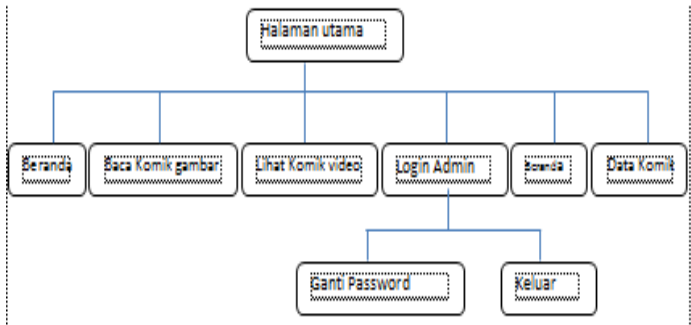

Gambar 4.13 Struktur Menu

F. Implementasi Hasil Rancangan Program

1. Tampilan Halaman Menu Home

Halaman utama ini merupakan tempat user dalam memperoleh informasi dan membaca komik digital secara gratis. Adapun gambar dapat dilihat di bawah ini.

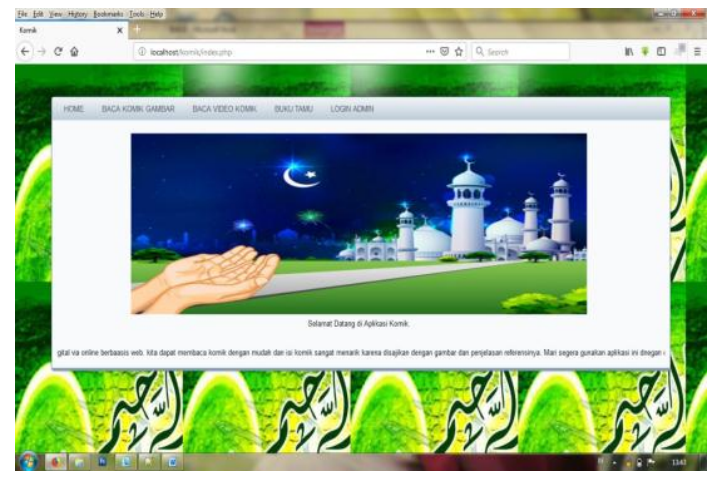

Gambar 4. 14 Tampilan Halaman Home

2. Tampilan Menu Baca Gambar Komik

Halaman ini user dapat melihat daftar judul komik dan user dapat membaca komik dgital ini dengan mudah. Adapun gambarnya dapat dilihat sebgai berikut di bawah ini.

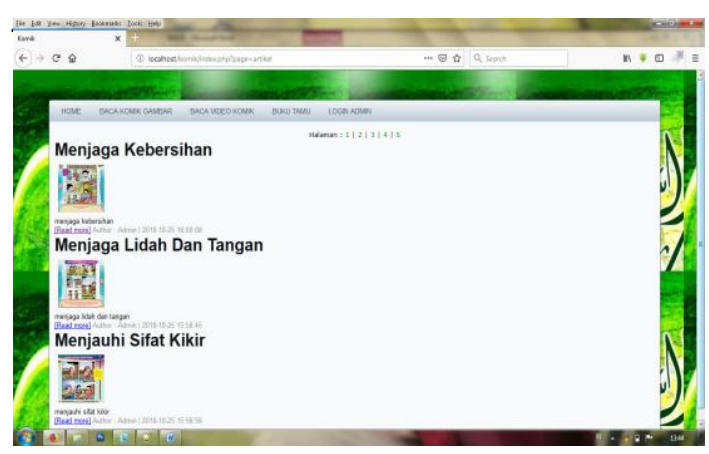

Gambar 4.15 Tampilan Menu Baca Komik

3. Tampilan Isi Komik Baca Gambar

Pada ini akan terdapat judul komik dan isi komik yang didalamnya juga terdapat teks dan gambar sebagai bacaan yang menarik. Adapun gambarnya dapat dilihat di bawah ini.

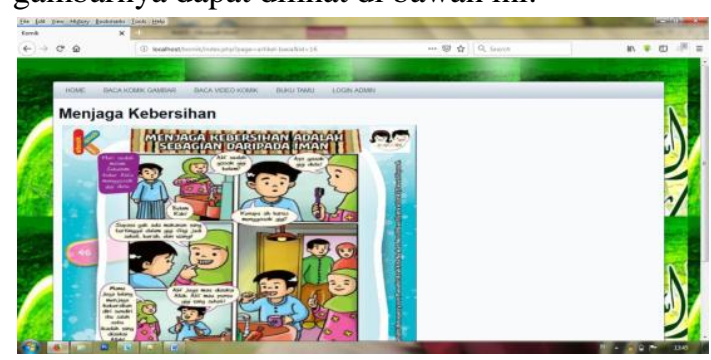

Gambar 4.16 Tampilan Isi Komik Baca Gambar

4. Tampilan Menu Lihat Video Komik

Halaman ini user dapat melihat daftar judul komik dan user dapat melihat dan mendengarkan komik digital ini dengan mudah. Adapun gambarnya dapat dilihat sebagai berikut di bawah ini. 


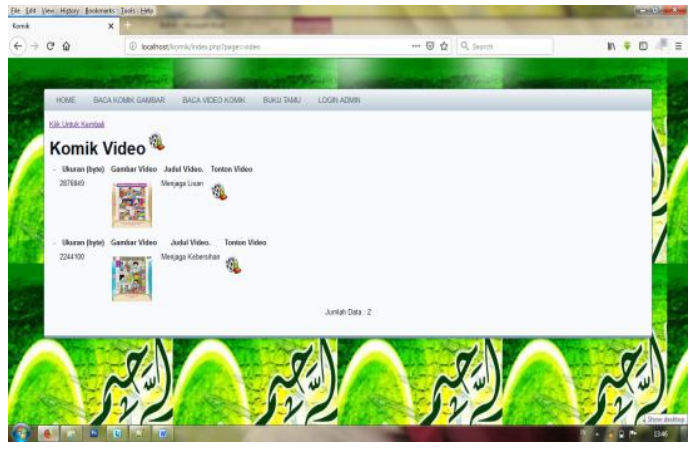

Gambar 4.17 Tampilan Menu Lihat avaideo Komik

5. Tampilan Isi Komik video Gambar

Pada ini akan terdapat judul komik dan isi komik yang di dalamnya juga terdapat teks dan gambar sebagai video yang menarik. Adapun videonya dapat dilihat di bawah ini.

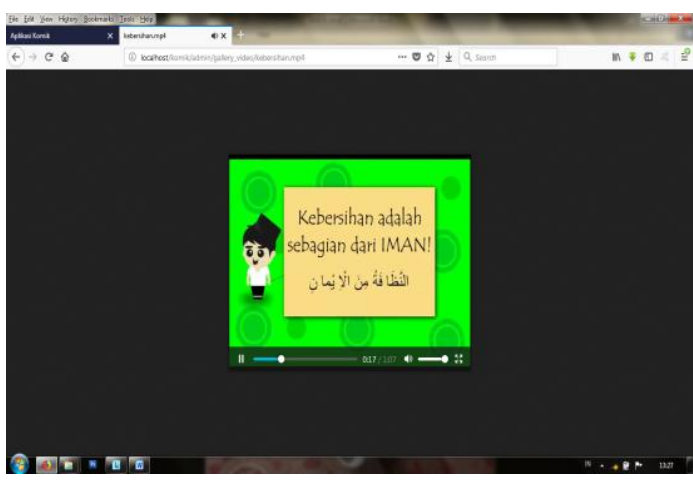

Gambar 4. 18 Tampilan Isi Komik video Gambar

6. Tampilan Menu Buku Tamu

Halaman ini berfungsi untuk menginputkan data buku tamu, Adapun gambarnya dapat dilihat sebagai berikut di bawah ini.

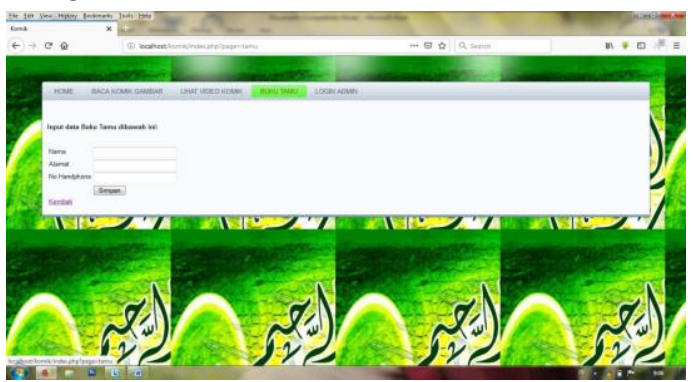

Gambar 4.19 Tampilan Menu Buku Tamu

7. Tampilan Menu Login Admin

Halaman login admin adalah tampilan form untuk login admin untuk masuk ke beranda komik.

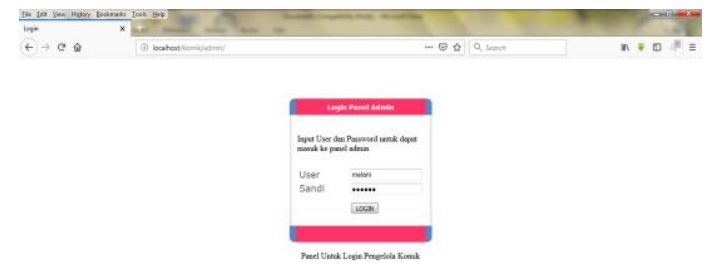

Gambar 4.20 Tampilan Menu Login Admin

8. Tampilan Menu Beranda Admin

Halaman ini merupakan tempat admin dalam menginputkan data komik, dan melihat data-data buku tamu, yang meliputi data komik, video komuk, buku tamu dang anti password. Adapun gambar dapat dilihat di bawah ini

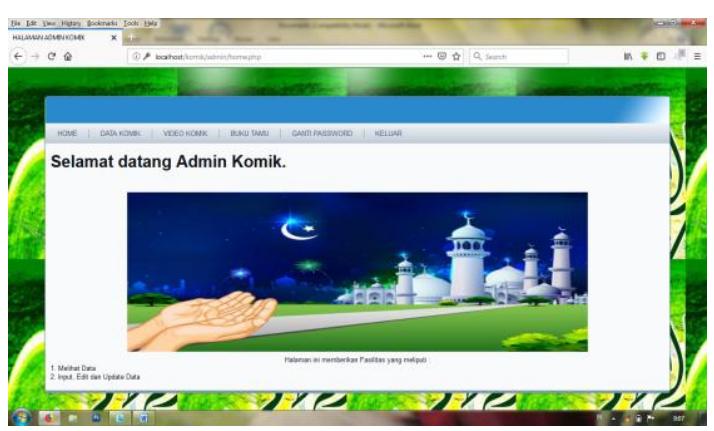

Gambar 4.21 Tampilan Tampilan Menu Beranda Admin

9. Tampilan Menu Data Komik

Halaman menu data komik berfungsi untuk admin dalam melakukan proses input, edit, update dan delete data komik digital. Adapun gambarnya dapat dilihat di bawah ini.

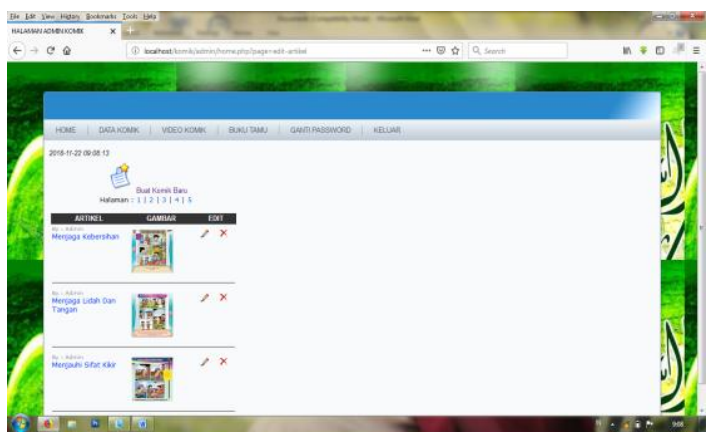

Gambar 4.22 Tampilan Menu Data Komik

10. Tampilan Menu VideoKomik

Halaman menu video komik berfungsi untuk admin dalam melakukan proses input, edit, update dan delete data komik digital. Adapun gambarnya dapat dilihat di bawah ini. 


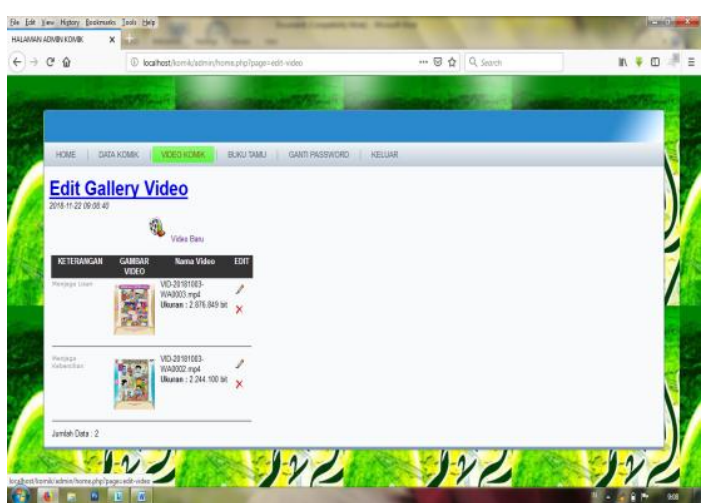

Gambar 4.23 Tampilan Menu Video Komik

11. Tampilan Menu Buku Tamu

Halaman ini berfungsi untuk melihat data buku tamu, mengedit dan menghapus Adapun gambarnya dapat dilihat di bawah ini

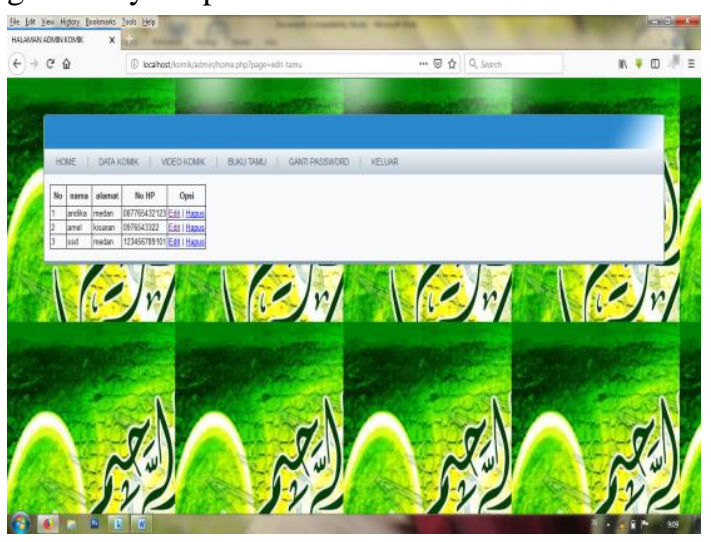

Gambar 4.24 Tampilan Menu Buku Tamu

12. Tampilan Menu Ganti Password

Halaman ini merupakan tempat admin untuk melakukan perubahan nama akun dan password login ke dalam halaman admin sistem. Adapun gambarnya dapat dilihat di bawah ini

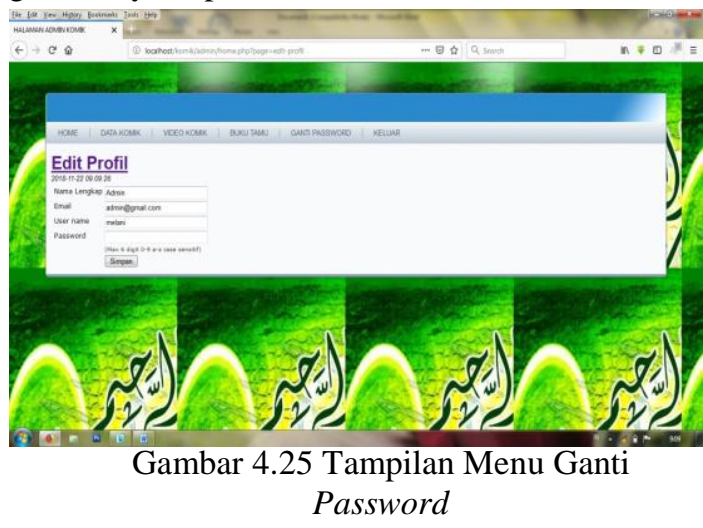

A. Kesimpulan

V. PENUTUP

Dari penjelasan yang telah diuraikan di atas dapat ditarik kesimpulan mengenai hal-hal dasar yang sangat erat kaitannya dengan perancangan aplikasi komiik hadist berbasis multimedia, maka dapat dismpulkan sebagai berikut :
1. Proses aplikasi hadist dibuat agar memudahkan pembaca dalam memahami isi cerita komik.

2. Data yang digunakan pada sistem yaitu menggunakan sistem unifed modelling language (UML), dengan menggunakan UML para pengguna lebih mudah menganalisa dan mendesain suatu sistem.

3. Dengan adanya aplikasi komik hadist ini, pengguna memiliki media tempat pembelajaran yang lebih efektif pada perkembangan jaman sekarang dan mempermudah pengguna dalam membaca komik hadist dan mengetahui isi cerita komik hadist tersebut.

\section{B. Saran}

Dari pembahasan pada bab-bab sebelumnya berkaitan Berdasarkan pembahasan memberikan saran untuk dapat membantu proses perancangan aplikasi komik hadist berbasis multimedia, yaitu sebagai berikut :

1. Dengan dibuatnya aplikasi komik hadist ini dapat menarik minat pengguna untuk lebih mengenal dan mempelajari hadist, karena dengan menggunakan visualisasi komik animasi akan mempermudah pengguna untuk memahami isi kandungan hadist.

2. Konsep perpaduan komik dengan animasi membuat penyajian komik menjadi lebih atraktif dan unik, sehingga berbeda dari konsep komik yang terkesan menoton.

3. Dengan diterapkanya aplikasi komik hadist pada platfrom desktop menjadikan resolusi gambar lebih maksimal, sehingga tingkat keterbacaan dialog teks menjadi lebih jelas.

\section{DAFTAR PUSTAKA}

[1] Ade Hendini. 2016. Pemodelan UML Sistem Informasi Monitoring Penjualan Dan Stok Barang. Jurnal Khatulistiwa Informatika. Vol. IV. No. 2.

[2] Anak Puspita Rahastri,Tengku A. Riza, ST., Rohmat Tulloh. 2015. Perancangan dan Ipmlementas Sistem InformasiSekolah (Studi Kasus Smp N 2 Patikraja Banyumaas. . Jurnal E-Procedding Of Apllied Science. Vol. 1. No. 3, Hal. 2660-2666, ISSN : 2442-5826.

[3] Angga Reza Palevi dan Krisnawati. 2013. Analisi dan Perancangan Sistem Informasi Penerimaan Peserta Didik Baru Berbasis Website Pada Smp N 2 MojosongoBoyolali. Jurnal Ilmiah Dasi. Vol. 14. No.4. Hal. 1-6, ISSN : 1411-3201

[4] Dewi Tresnawati, Eri Satria, Yudistria Adinugraha. 2016. Pengembangan Aplikasi Komik Hadist Berbasis Multimedia, Jurnal Algoritma, Vol. 13. No. 1, Hal. 99-105, ISSN : 2302-7339

[5] Irene Hasan dan Annisa Jiwojati Utami. 2018. Tinjauan Desai Karakter Komik Mice 
Terhadap Kesesuain Karakter Indonesia, Jurnal Magenta. Vol. 2. No. 1,271-288.

[6] Liza Yulianti dan Harry Aspriono. 2011. Website Unit Pelaksana Teknis Dinas (Uptd/0 Puskesmas Jembatan Kecil Kota Bengkulu Menggunakan Adobe Dreamweaver Cs3. Jurnal Media Infotama. Vol. 7. No. 2. Hal.51-76, ISSN : $1858-2680$

[7] Nataniel Denge dan Heliza Ramania Hatta. (2009). Perancanagan Sistem Informasi Terpadu Pemerintah Daerah Kabupaten Paser. Jurnal Informatika Mulawarman. Vol. 4. No. 1, 47-54

[8] Septiana Firdaus, Dhami Johar Damiri. 2012. Perancangan Aplikasi Multimedia Interaktifcompany Profile Generic (Studi Kasus Cv. Genetic.Jurnal Algoritma Sekolah Tinggi Teknologi Garut. Vol. 01. No. 09, Hal. 1-10, ISSN : 2302-7339.

[9] Suhartini. 2017.Aplikasi Alat BANTU Belajar Bahasa Inggris Sekolah DasarMenggunakan Adobe Flash Cs.6 (Studi Kasus: Sdit Fathona Baturaja).Jurnal Sistem Informasi Dan Komputererisasi Akuntansi (Jsk). Vol. 01. No. 01, Hal. 71-80, ISSN : 2579-4477. 